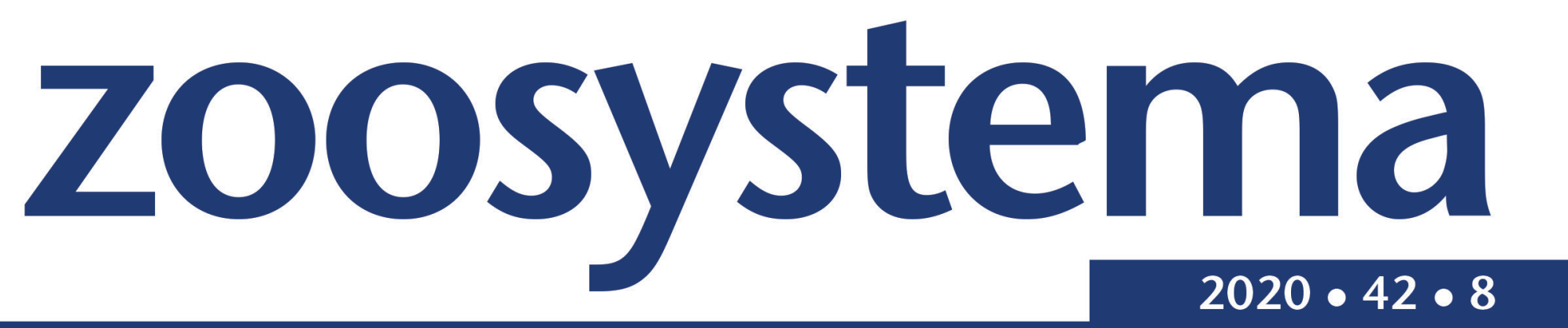

\title{
Three new species of Ischioscia Verhoeff, 1928 (Isopoda, Oniscidea, Philosciidae) from Serranía de Perijá, Andean Cordillera, Colombian Caribbean
}

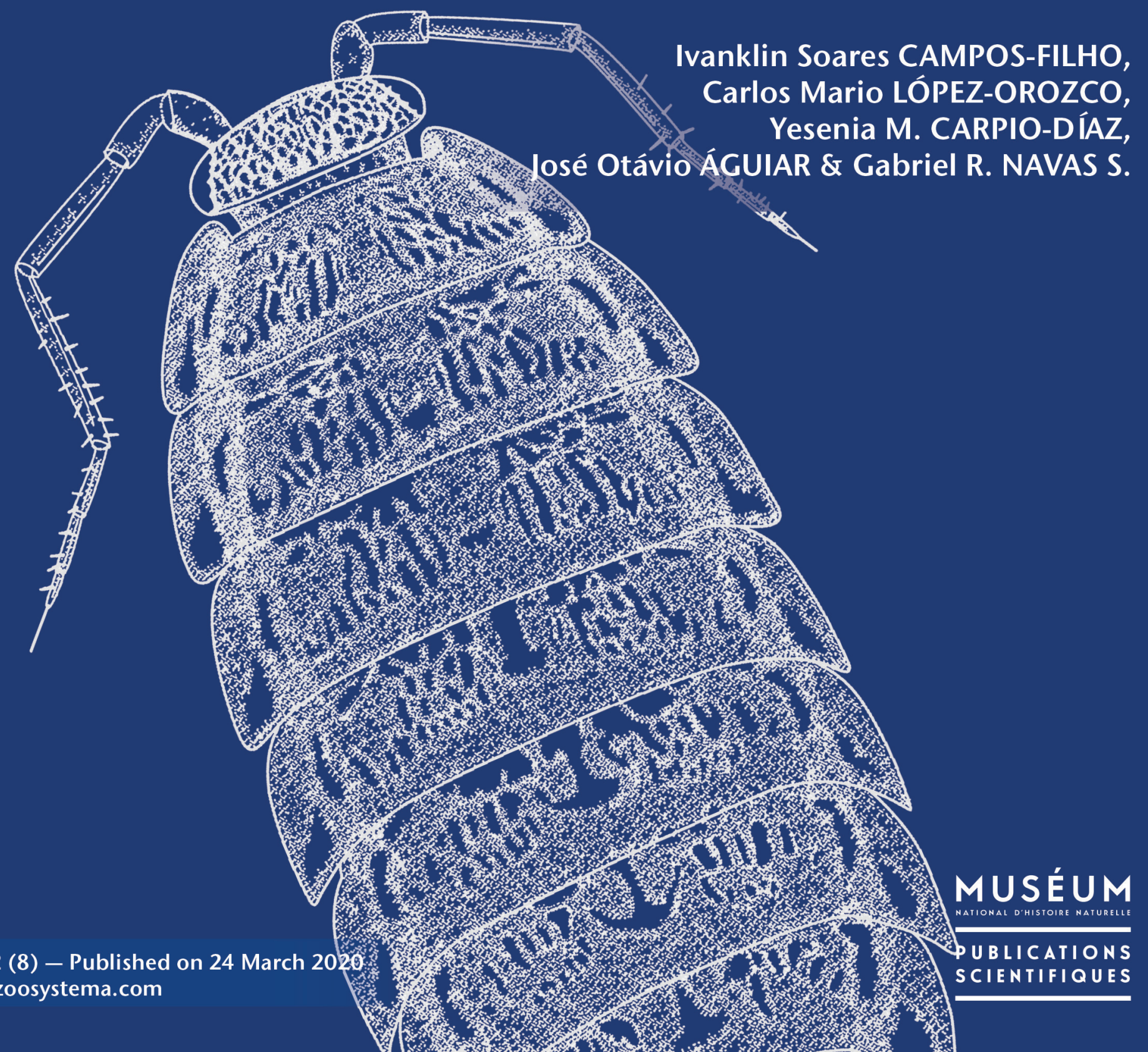


DiRECTEUR DE LA PUBlication: Bruno David

Président du Muséum national d'Histoire naturelle

RÉDACTRICE EN CHEF / EDITOR-IN-CHIEF : Laure Desutter-Grandcolas

AsSISTANTS DE RÉDACTION / AsSISTANT EDITORS: Anne Mabille (zoosyst@mnhn.fr)

Mise en page / Page Layout: Anne Mabille

COMITÉ SCIENTIFIQUE / SCIENTIFIC BOARD:

James Carpenter (AMNH, New York, États-Unis)

Maria Marta Cigliano (Museo de La Plata, La Plata, Argentine)

Henrik Enghoff (NHMD, Copenhague, Danemark)

Rafael Marquez (CSIC, Madrid, Espagne)

Peter Ng (University of Singapore)

Norman I. Platnick (AMNH, New York, États-Unis)

Jean-Yves Rasplus (INRA, Montferrier-sur-Lez, France)

Jean-François Silvain (IRD, Gif-sur-Yvette, France)

Wanda M. Weiner (Polish Academy of Sciences, Cracovie, Pologne)

John Wenzel (The Ohio State University, Columbus, États-Unis)

COUVERTURE / COVER:

Ischioscia herrerai López-Orozco, Carpio-Díaz \& Campos-Filho n. sp., female paratype (CUDC-CRU 47), habitus, dorsal view.

Zoosystema est indexé dans / Zoosystema is indexed in:

- Science Citation Index Expanded (SciSearch ${ }^{\circledR}$ )

- ISI Alerting Services ${ }^{\circledR}$

- Current Contents ${ }^{\circledR} /$ Agriculture, Biology, and Environmental Sciences ${ }^{\circledR}$

- Scopus ${ }^{\circledR}$

Zoosystema est distribué en version électronique par / Zoosystema is distributed electronically by:

- BioOne ${ }^{\circledR}$ (http://www.bioone.org)

Les articles ainsi que les nouveautés nomenclaturales publiés dans Zoosystema sont référencés par / Articles and nomenclatural novelties published in Zoosystema are referenced by:

- ZooBank ${ }^{\circledR}$ (http://zoobank.org)

Zoosystema est une revue en flux continu publiée par les Publications scientifiques du Muséum, Paris / Zoosystema is a fast track journal published by the Museum Science Press, Paris

Les Publications scientifiques du Muséum publient aussi / The Museum Science Press also publish:

Adansonia, Geodiversitas, Anthropozoologica, European Journal of Taxonomy, Naturae, Cryptogamie sous-sections Algologie, Bryologie, Mycologie.

Diffusion - Publications scientifiques Muséum national d'Histoire naturelle

CP 41 - 57 rue Cuvier F-75231 Paris cedex 05 (France)

Tél. : 33 (0)1 40794805 / Fax: 33 (0)1 40793840

diff.pub@mnhn.fr / http://sciencepress.mnhn.fr

(C) Publications scientifiques du Muséum national d'Histoire naturelle, Paris, 2020

ISSN (imprimé / print): 1280-9551/ ISSN (électronique / electronic): 1638-9387 


\title{
Three new species of Ischioscia Verhoeff, 1928 (Isopoda, Oniscidea, Philosciidae) from Serranía de Perijá, Andean Cordillera, Colombian Caribbean
}

\author{
Ivanklin Soares CAMPOS-FILHO \\ Programa de Pós-Graduação em Recursos Naturais, \\ Universidade Federal de Campina Grande, Campina Grande, Paraíba (Brazil) \\ ivanklin.filho@gmail.com (corresponding author) \\ Carlos Mario LÓPEZ-OROZCO \\ Yesenia M. CARPIO-DÍAZ
}

Grupo de Investigación Hidrobiología, Universidad de Cartagena, Programa de Biología, Campus San Pablo, Cartagena de Indias (Colombia) and Grupo de Investigación en Biología Descriptiva y Aplicada, Universidad de Cartagena, Programa de Biología, Campus San Pablo, Cartagena de Indias (Colombia) clopezo1@unicartagena.edu.co; ycarpiod@unicartagena.edu.co

José Otávio ÁGUIAR

Programa de Pós-Graduação em Recursos Naturais, Universidade Federal de Campina Grande, Campina Grande, Paraíba (Brazil) otavio.j.aguiar@gmail.com

Gabriel R. NAVAS S. Grupo de Investigación Hidrobiología, Universidad de Cartagena, Programa de Biología Campus San Pablo, Cartagena de Indias (Colombia) grnavas@gmail.com

Submitted on 27 March 2019 | Accepted on 15 July 2019 | Published on 24 March 2020 urn:Isid:zoobank.org:pub:B69957FC-A84A-49F5-9527-B1C9E2D138BB

Campos-Filho I. S., López-Orozco C. M., Carpio-Díaz Y. M., Águiar J. O., Navas S. G. R. 2020. - Three new species of Ischioscia Verhoeff, 1928 (Isopoda, Oniscidea, Philosciidae) from Serranía de Perijá, Andean Cordillera, Colombian Caribbean. Zoosystema 42 (8): 115-130. https://doi.org/10.5252/zoosystema2020v42a8. http://zoosystema.com/42/8

KEY WORDS Ischiosciini, Serranía de Perijá, Andean ecosystem Neotropical new species.

MOTS CLÉS Ischiosciini, Serranía de Perijá, écosystème andin, néotropical, espèces nouvelles.

\section{ABSTRACT}

The genus Ischioscia Verhoeff, 1928 is one of the most diverse genera in the Philosciidae Kinahan, 1857. To date, the genus comprises 26 species distributed in tropical and subtropical areas of the Neotropical region. In this work three new species from Serranía de Perijá, Andean Cordillera, Colombian Caribbean, are described: Ischioscia herrerai López-Orozco, Carpio-Díaz \& Campos-Filho n. sp., Ischioscia perijaensis Carpio-Díaz, López-Orozco \& Campos-Filho n. sp. and Ischioscia unicartagenae Campos-Filho, Carpio-Díaz \& López-Orozco n. sp. In addition, an identification key for all species of the genus is given.

RÉSUMÉ

Trois nouvelles espèces d'Ischioscia Verhoeff, 1928 (Isopoda, Oniscidea, Philosciidae) de Serranía de Perijá, Cordillère des Andes, Caraïbes colombiennes.

Le genre Ischioscia Verhoeff, 1928 est l'un des genres les plus divers chez les Philosciidae Kinahan, 1857. À ce jour, le genre comprend 26 espèces réparties dans les zones tropicales et subtropicales de la région néotropicale. Dans ce travail, trois nouvelles espèces de Serranía de Perijá, Cordillère Andine, Colombie Caraïbes, sont décrites : Ischioscia herrerai López-Orozco, Carpio-Díaz \& Campos-Filho n. sp., Ischioscia perijaensis Carpio-Díaz, López-Orozco \& Campos-Filho n. sp. et Ischioscia unicartagenae Campos-Filho, CarpioDíaz \& López-Orozco n. sp. De plus, une clé d’identification pour toutes les espèces du genre est donnée. 


\section{INTRODUCTION}

The family Philosciidae Kinahan, 1857 constitutes one of the most diverse families within the Oniscidea Latreille, 1802 (Schmalfuss 2003; Sfenthourakis \& Taiti 2015). The family comprises approximately 600 species distributed in 115 genera and constitutes an important micro-fauna component in tropical and humid environments (Leistikow 2001a; Campos-Filho et al. 2014, 2017, 2018; Taiti 2016; López-Orozco et al. 2016, 2017).

The genus Ischioscia Verhoeff, 1928 is one of the most diverse genera of Philosciidae in the Neotropical region (Leistikow \& Schmidt 2002). Currently, it includes 26 species distributed in Brazil, Colombia, Costa Rica, Ecuador, French Guiana (doubtful record), Guatemala, Lesser Antilles (Dominica and Guadalupe), Panama, Peru and Venezuela (Schmalfuss 2003; Leistikow \& Schmidt 2002; Taiti 2016). In Colombia, two species are known, I. sturmi (Vandel, 1972) recorded from Cundinamarca, Huila, Putumayo and Nariño departments, and I. curvaculeus Leistikow, 2001 from Magdalena department (Vandel 1972; Leistikow 2001c). Moreover, the genus is morphologically well defined (see Schmalfuss 1980; Leistikow 1997, 2000, 2001a, b; Leistikow \& Schmidt 2002).

In the present work three new species of Ischioscia from Serranía de Perijá, Andean Cordillera, Colombian Caribbean, are described. These are the first records of the genus for Serranía de Perijá. In addition, an identification key for all species in the genus is given.

\section{MATERIAL AND METHODS}

The specimens were stored in $75 \%$ ethanol and identifications were based on morphological characters. The images were obtained with the aid of Axio Lab. A1 microscope and SteREO Discovery.V12 ZEISS stereomicroscope with adapted Axiocam ERc 5 s camera. The final illustrations were prepared using the software GIMP (v. 2.8) with methods proposed by Coleman (2006) and Montesanto $(2015,2016)$. A key to all the species of Ischioscia is given after Leistikow \& Schmidt (2002). The type material is deposited in the Crustaceans Collection of the Programa de Biología, Universidad de Cartagena (CUDC-CRU), Cartagena de Indias and in the Isopods Collection of the Instituto de Ciencias Naturales, Universidad Nacional de Colombia (ICN-CI), Bogotá, Colombia.

\section{STUDY AREA}

The material was collected in the Andean forest on the western flank of the Serranía de Perijá at an altitude of $2800 \mathrm{~m}$. The area is inserted between the departments of Cesar and La Guajira, North-eastern Colombia (high-Andean-subparamo zone). According to Köppen's criteria (Rubel \& Kottek 2010), this area shows warm temperate climate, dry winter and warm summer (Cwb), typical of the Andes. The average temperature is around $18^{\circ} \mathrm{C}$ with mild summer (temperature not surpassing $22^{\circ} \mathrm{C}$ in the warmest month). The rainfall distribution regime is bimodal, tetra-seasonal and not very well defined. The total annual rainfall is $c .1200 \mathrm{~mm}$, with an average of $97 \mathrm{~mm}$ monthly and multi-year in $103 \mathrm{~mm}$ monthly. The periods of highest rainfall occur from May to June and August to November, with the highest precipitation in October (c. $240 \mathrm{~mm})$. The dry season occurs from December to April and in July, with the driest moment in February (c. $20 \mathrm{~mm}$ ) (Arellano-P. et al. 2007).

\section{SYSTEMATIC ACCOUNT}

Family PHILOSCIIDAE Kinahan, 1857

Tribe IsCHIOSCIINI Leistikow, 2001

Genus Ischioscia Verhoeff, 1928

TYPE SPECIES. - Ischioscia lobifera Verhoeff, 1928 by monotypy [junior synonym of Philoscia variegata Dollfus, 1893].

DiagnOSIS. — See Schmalfuss (1980) and Leistikow (1997).

Ischioscia herrerai López-Orozco, Carpio-Díaz \& Campos-Filho n. sp. (Figs 1-3)

urn:Isid:zoobank.org:act:84046969-EDD0-4A8E-8175-7C645A1BB873

TYPe MATERIAL. - Holotype. Colombia • ơ; Quebrada El Jordán, El Contento Village, San José de Oriente, La Paz, Cesar; $10^{\circ} 17^{\prime} 40.4$ ”N, 7255'52.1"W; 13.VIII.2015; Y. Herrera-Medina leg.; CUDCCRU 33.

Paratypes. Colombia $\bullet 10^{\top}$ (part in micropreparations); same locality and date as for holotype; C. M. López-Orozco leg.; CUDC-CRU $45 \cdot 1$ ( (part in micropreparations); same locality and date as for holotype; C. M. López-Orozco leg.; CUDC-CRU 47 • 2 o", 3 \%; same locality and date as for holotype; C. M. López-Orozco leg.; ICN-CI-86 • 12 o', 37 \%; same locality and date as for holotype; C. M. López-Orozco leg.; CUDC-CRU-37 • $10^{\prime \prime}, 13$ \%; Cerro Pintao, La Jagua del Pilar, La Guajira; $10^{\circ} 25^{\prime} 41.8^{\prime \prime} \mathrm{N}, 72^{\circ} 56^{\prime} 8.3^{\prime \prime W}$; 10.VIII.2015; C. M. López-Orozco leg.; CUDC-CRU-36.

ETymology. - The new species is named after Yeison HerreraMedina who collected part of the specimens used in this study.

\section{DESCRIPTION}

Maximum body size: male $9 \mathrm{~mm} \times 3.5 \mathrm{~mm}$ (holotype); female $9.8 \mathrm{~mm} \times 3.8 \mathrm{~mm}$. Body as in Fig. 1A. Colour dark brown: antennal peduncle with first and second articles slightly pigmented, third to fifth articles and flagellum strongly pigmented; cephalon with irregular unpigmented spots; pereon with longitudinal unpigmented areas on paramedian region, pereonites 4-7 with one longitudinal unpigmented spot on median portion, epimera with two distinct unpigmented spots near posterior portions; pleon, telson and uropod exopods strongly pigmented (Fig. 1A). Dorsal surface bearing short triangular scale-setae (Fig. 1B). Cephalon (Fig. 1C, D) lateral lobes and frontal line absent, supraantennal line almost straight; vertex dorsoventrally flattened 


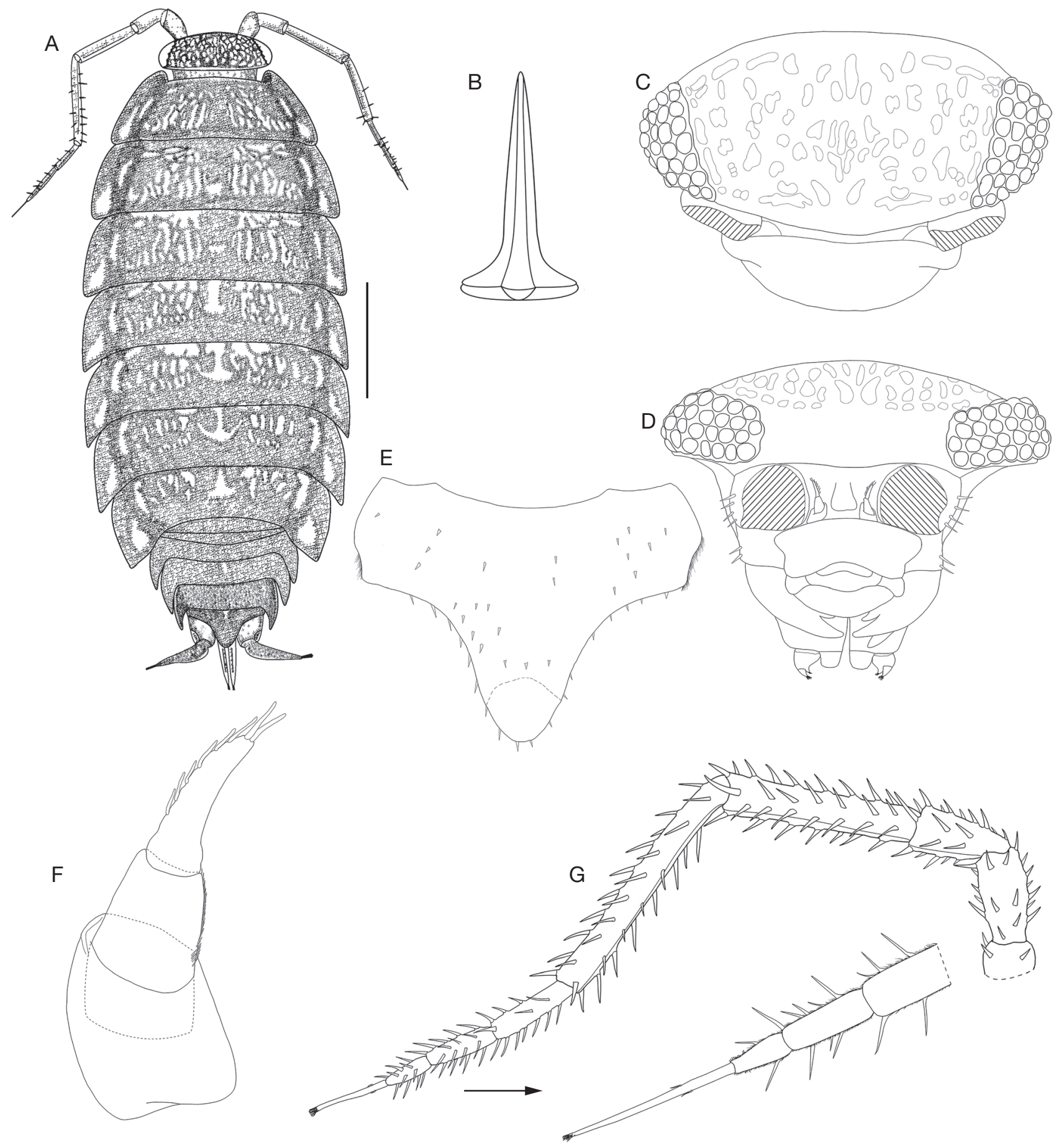

FIG. 1. - Ischioscia herrerai López-Orozco, Carpio-Díaz \& Campos-Filho n. sp., female paratype (CUDC-CRU 47): A, habitus, dorsal view; B, dorsal scale-seta; C, cephalon, dorsal view; D, cephalon, frontal view; E, telson; F, antennula; G, antenna. Scale bar: $1 \mathrm{~mm}$.

with prominent compound eyes on lateral protrusions; eyes with 27 ommatidia arranged in four rows. Pleon (Fig. 1A) narrower than pereon, neopleurae 3-5 well developed and directed backwards. Telson (Fig. 1E) with lateral margins concave, apex rounded. Antennula (Fig. 1F) of three articles, distal article bearing six superimposed aesthetascs plus apical pair. Antenna (Fig. 1G) when extended posteriorly reaching anterior portion of pereonite 3; flagellum of three articles subequal in length, apical organ very long. Mandibles with molar penicil composed of seven branches, left mandible (Fig. 2A) with $2+1$ penicils, right mandible (Fig. 2B) with $1+1$ penicils. Maxillula (Fig. 2C) inner endite with distal margin rounded bearing two hairy penicils; outer endite of $4+5$ teeth, two of them with cleft apex. Maxilla (Fig. 2D) outer 


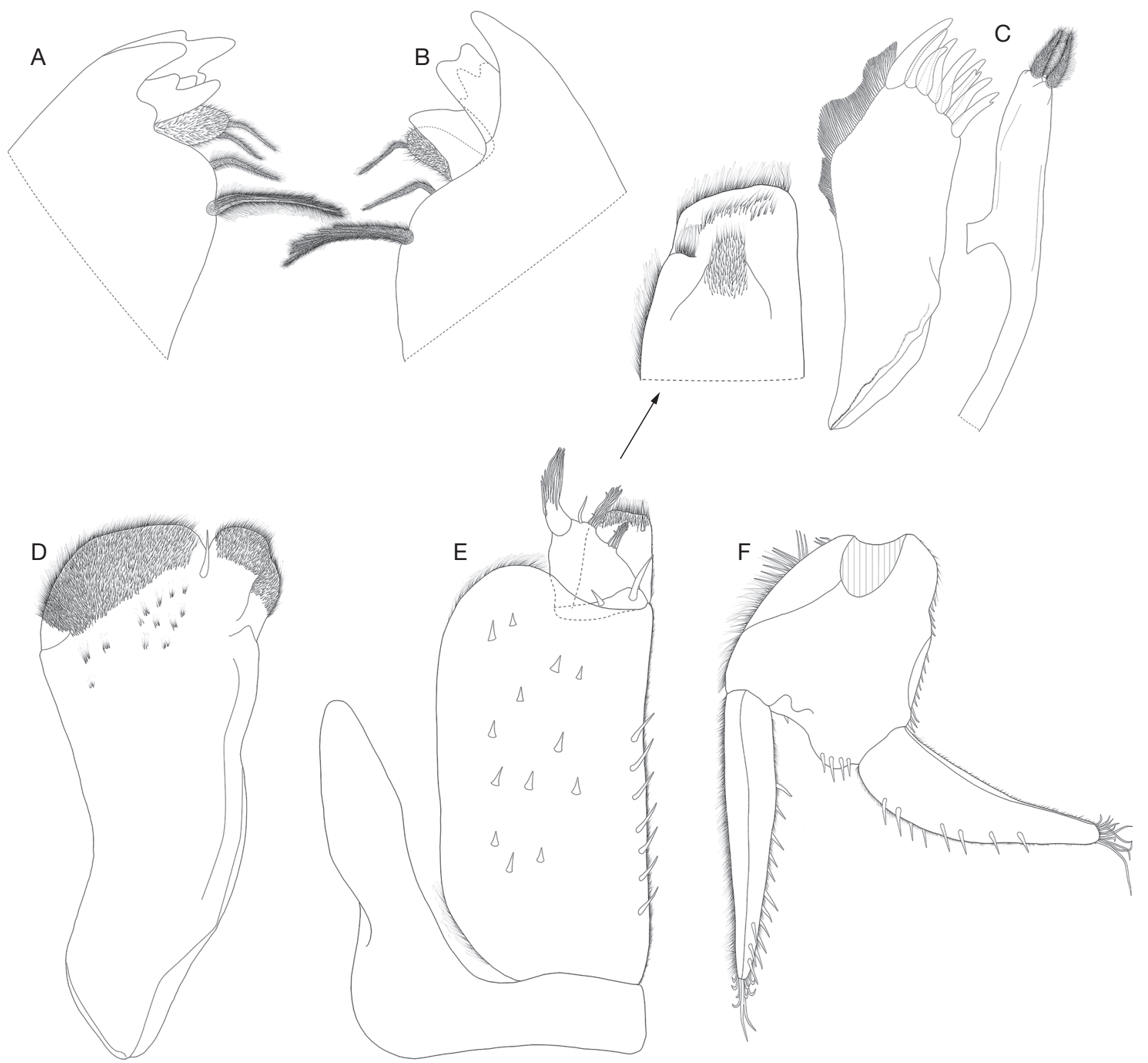

FIG. 2. - Ischioscia herrerai López-Orozco, Carpio-Díaz \& Campos-Filho n. sp., female paratype (CUDC-CRU 47): A, left mandible; B, right mandible; C, maxillula inner endite (right), outer endite (left); D, maxilla; E, maxilliped; F, uropod.

lobe almost three times as wide as inner lobe, distal margin rounded and covered with thin setae, one thick seta on inner portion; inner lobe rounded bearing thick setae. Maxilliped (Fig. 2E) basis rectangular bearing sparse setae; palp with two setae on proximal article; endite sub-rectangular, rostral and caudal surfaces hairy, medial seta not surpassing distal margin. Uropod (Fig. 2F) protopod and exopod grooved on lateral margin, exopod as long as endopod, endopod inserted proximally. Pereopods 1-7 long and slender; carpus 1 with antennal grooming brush transverse and distal setae apically cleft; dactylus of two claws, inner claw not surpassing outer claw, ungual seta long, dactylar seta apically plumose. Pleopod exopods without respiratory areas.

\section{Male}

Pereopods 1-3 with carpus enlarged, rostral portion bearing dense field of setae. Pereopod 1 and 2 propodus and pereopods 1-3 merus bearing dense field of setae on rostral and sternal portions (Fig. 3A). Pereopod 7 (Fig. 3B) ischium with rounded lobe bearing one strong seta on caudal surface, and distal sternal portion prominent. Genital papilla (Fig. 3C) truncated apically, triangular ventral shield and two apical orifices. Pleopod 1 (Fig. 3D) exopod cordiform, inner margin slightly sinuous, outer margin with distinct lateral incision, apical lobe triangular, directed outwards; endopod stout, almost twice as long as exopod, distal portion straight with row of small setae on medial portion, apex rounded with 

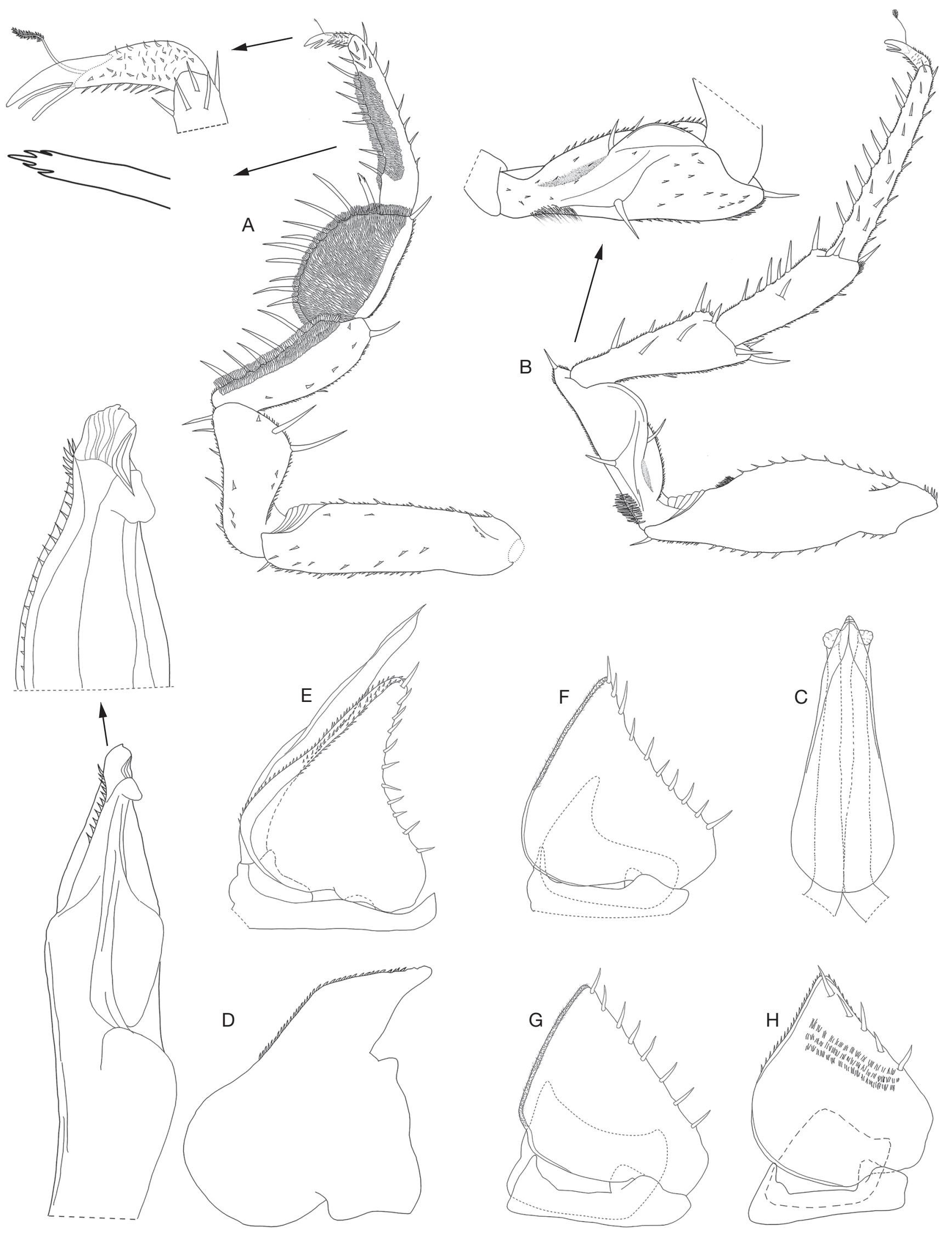

FIG. 3. - Ischioscia herrerai López-Orozco, Carpio-Díaz \& Campos-Filho n. sp., male paratype (CUDC-CRU 45): A, pereopod 1; B, pereopod 7; C, genital papilla; D, pleopod 1, exopod (right), endopod (left); E, pleopod 2; F, pleopod 3; G, pleopod 4; H, pleopod 5. 
subapical lobe on outer margin. Pleopod 2 (Fig. 3E) exopod triangular, outer margin concave bearing several setae; endopod stout, longer than exopod, apex pointed. Pleopods 3 and 4 as in Fig. 3F and G, respectively. Pleopod 5 (Fig. 3H) exopod triangular, transverse rows of scales, outer margin straight bearing five setae.

\section{REMARKS}

In the shape of the male pleopod 1 exopod Ischioscia herrerai López-Orozco, Carpio-Díaz \& Campos-Filho n. sp. resembles I. martinae Leistikow, 1997 and I. muelleri Leistikow, 1997, but it differs in the shape of the male pereopod 1-2 carpus and the presence of a lobe on the male pereopod 7 ischium. In having a lobe on the male pereopod 7 ischium $I$. herrerai López-Orozco, Carpio-Díaz \& Campos-Filho n. sp. is similar to $I$. variegata (Dollfus, 1893), I. panamaensis Leistikow, 1999, I. marmorata Leistikow, 2000, I. hirsuta Leistikow, 2001, I. colorata Leistikow, 2001, I. pariae Leistikow, 2001, I. guamae Leistikow, 2001, and I. trifasciata Leistikow, 2001; however, it differs from all these species in the colour pattern, shape of the male pereopods 1-3 carpus, of the lobe on the male pereopod 7 ischium, and of the male pleopod 1 exopod.

Ischioscia perijaensis Carpio-Díaz, López-Orozco \& Campos-Filho n. sp. (Figs 4-6)

urn:Isid:zoobank.org:act:DC17E8EB-202D-4FBE-BB4A-40F721BD516A

TYPe MATERIAL. - Holotype. Colombia • $0^{\prime}$ (parts in micropreparations); Quebrada El Jordán, El Contento Village, San José de Oriente, La Paz, Cesar; $10^{\circ} 17^{\prime} 40.4^{\prime}$ N, $72^{\circ} 55^{\prime} 52.1$ 'W; 14.VIII.2015; C. M. López-Orozco leg.; CUDC-CRU 40.

ETYMology. - The new species is named after the locality where the specimens were collected: Serranía de Perijá.

\section{DESCRIPTION}

Body size: $6 \mathrm{~mm} \times 2.9 \mathrm{~mm}$. Body as in Fig. 4A. Colour dark brown: antennal peduncle with first and second articles slightly pigmented, third to fifth article and flagellum strongly pigmented; cephalon with irregular unpigmented spots; pereon with longitudinal unpigmented spots on paramedian region, epimera with one unpigmented spot; pleon and telson strongly pigmented; uropods slightly pigmented (Fig. 4A). Dorsal surface bearing short triangular scale-setae (Fig. 4B). Cephalon (Fig. 4C, D) without lateral lobes, frontal line and supra-antennal slightly bent downwards medially; vertex dorsoventrally flattened with prominent compound eyes on lateral protrusions; eyes with 25 ommatidia arranged in four rows. Pleon (Fig. 4A) narrower than pereon, neopleurae 3-5 well developed and directed backwards. Telson (Fig. 4E) with lateral margins concave, apex rounded. Antennula (Fig. 4F) of three articles, distal article bearing six aesthetascs in three sets plus apical pair. Antenna (Fig. 4G) when extended posteriorly reaching anterior margin of pereonite 3; flagellum of three articles subequal in length, apical organ very long. Mandibles with molar penicil composed of 5 to 6 branches, left mandible (Fig. 5A) with $2+1$ penicils, right mandible (Fig. 5B) with $1+1$ penicils. Maxillula (Fig. $5 \mathrm{C}$ ) inner endite with distal margin rounded bearing two stout hairy penicils; outer endite of $4+6$ teeth, two of them with cleft apex. Maxilla (Fig. 5D) outer lobe twice as wide as inner lobe, distal margin rounded and covered with thin setae, two thick setae on inner portion; inner lobe rounded bearing thick setae. Maxilliped (Fig. 5E) basis rectangular bearing sparse setae; palp with two setae on proximal article; endite sub-rectangular, median seta surpassing distal margin, strong seta on distal outer portion, ventral surface setose. Uropod (Fig. 5F) protopod and exopod grooved on lateral margin, exopod longer than endopod, endopod inserted proximally. Pereopods 1-7 long and slender, carpus 1 with antennal grooming brush transverse; dactylus of two claws, inner claw not surpassing outer claw, ungual seta long, dactylar seta apically plumose. Pleopod exopods without respiratory areas.

\section{Male}

Pereopod 1 (Fig. 6A) with merus, carpus and propodus, and pereopod 2 merus and carpus bearing dense field of setae. Pereopod 7 (Fig. 6B) ischium with rounded depression on rostral surface, sternal margin bearing brush of thin setae on central part. Genital papilla (Fig. 6C) truncated apically, triangular ventral shield and two apical orifices. Pleopod 1 (Fig. 6D) exopod cordiform, inner margin almost straight, outer margin without lateral incision, distal margin rounded, lateral process short; endopod stout, almost twice as long as exopod, distal portion straight bearing row of small setae on medial margin and subapical lobe on outer margin. Pleopod 2 (Fig. 6E) exopod triangular, outer margin concave bearing several setae; endopod stout, slightly longer than exopod. Pleopods 3 and 4 as in Fig. 6F and G, respectively. Pleopod 5 (Fig. 6H) exopod rhomboid slightly wider than long, transverse rows of scales, outer margin sinuous bearing four setae, inner and outer margins densely covered with thin setae.

\section{REMARKS}

Ischioscia perijaensis Carpio-Díaz, López-Orozco \& CamposFilho n. sp. is readily distinguishable from their congeners in having the male pereopod 1 carpus not enlarged, the male pereopod 7 ischium with a rounded depression on rostral surface, and the male pleopod 1 exopod cordiform with lateral process short and outer margin lacking the lateral incision. In addition, I. perijaensis Carpio-Díaz, López-Orozco \& Campos-Filho n. sp. differs from $I$. herrerai López-Orozco, Carpio-Díaz \& Campos-Filho n. sp. in having the male pereopod 1 carpus not enlarged, the male pereopod 7 ischium without lobe and in the shape of the male pleopod 1 exopod. 

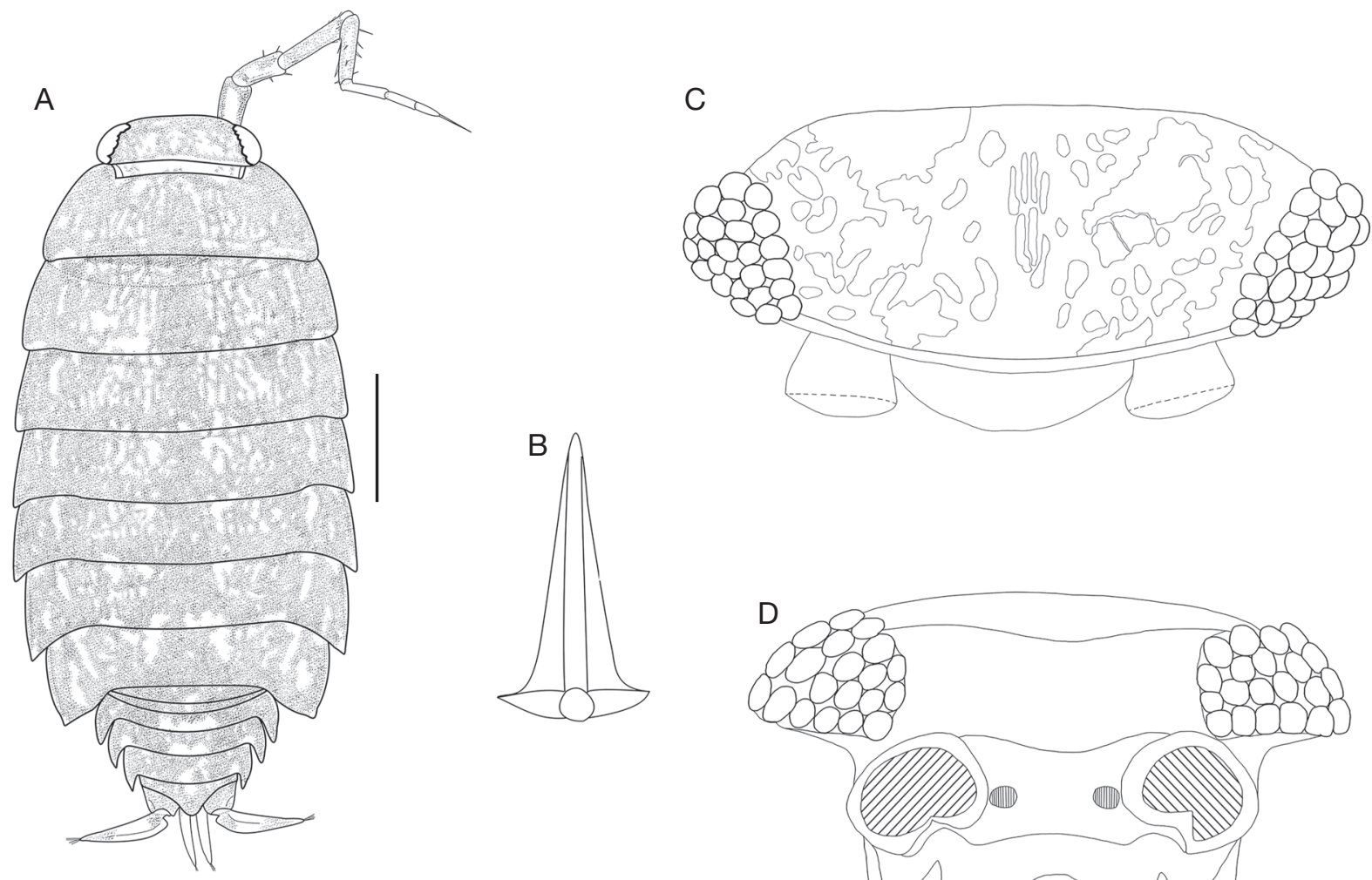

E
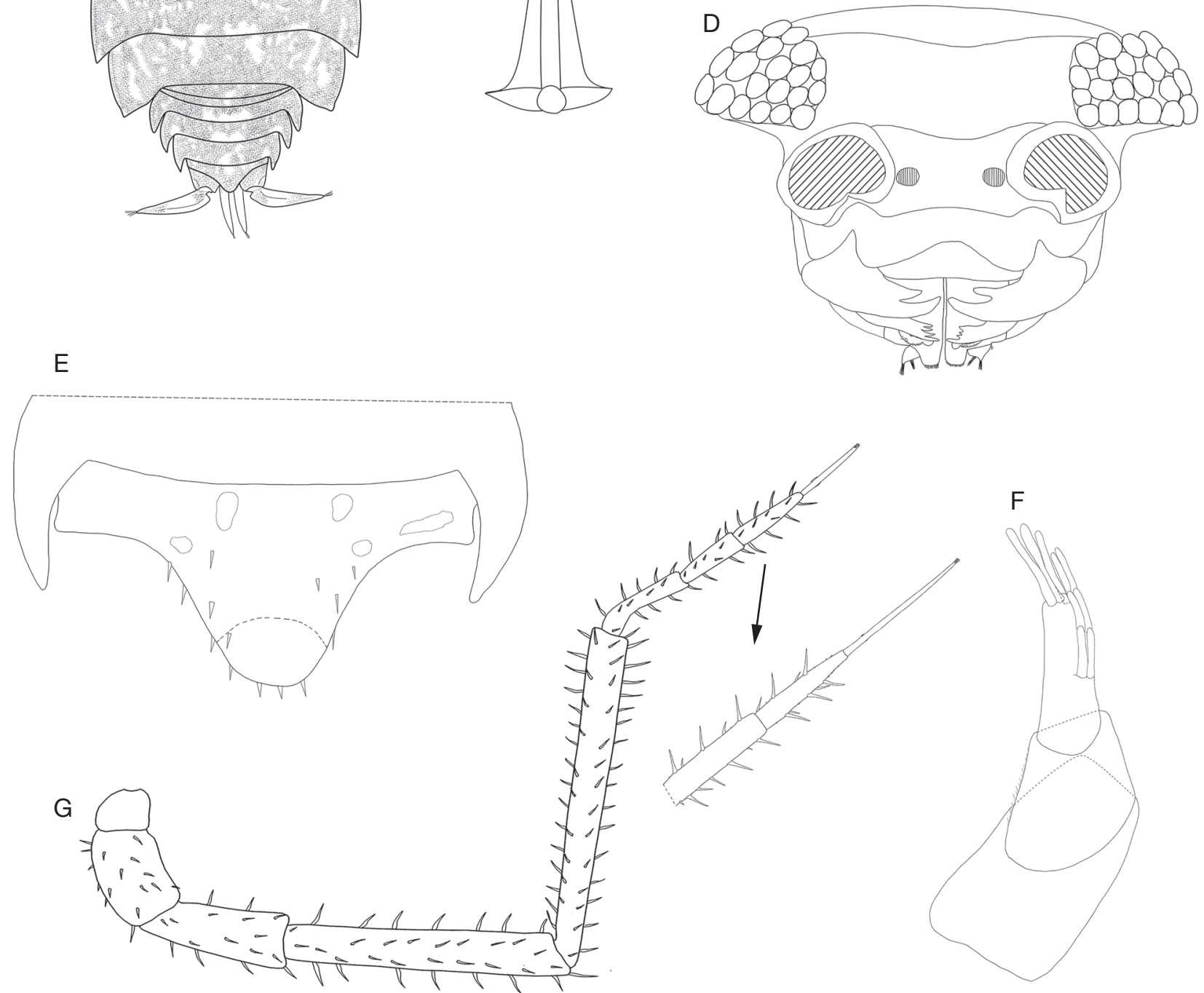

FIG. 4. - Ischioscia perijaensis Carpio-Díaz, López-Orozco \& Campos-Filho n. sp., male paratype (CUDC-CRU 40): A, habitus, dorsal view; B, dorsal scale-seta; C, cephalon, dorsal view; D, cephalon, frontal view; E, pleonite 5 and telson; F, antennula; $\mathbf{G}$, antenna. Scale bar: $1 \mathrm{~mm}$. 


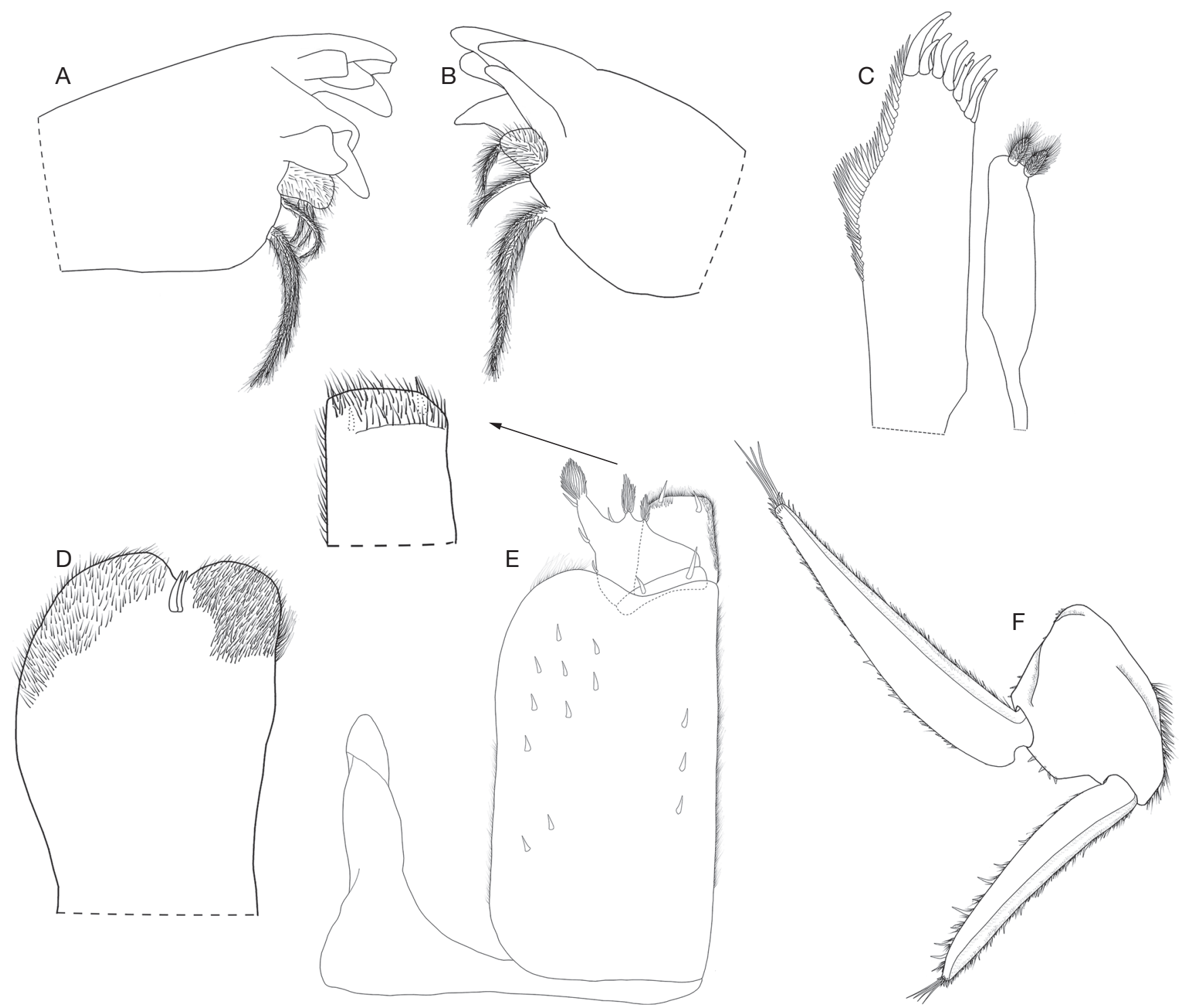

FIG. 5. - Ischioscia perijaensis Carpio-Díaz, López-Orozco \& Campos-Filho n. sp., male paratype (CUDC-CRU 40). A, left mandible; B, right mandible; C, maxillula inner endite (right), outer endite (left); D, maxilla; E, maxilliped; F, uropod.

\section{Ischioscia unicartagenae Campos-Filho,} Carpio-Díaz \& López-Orozco n. sp.

(Figs 7-9)

\section{urn:Isid:zoobank.org:act:38E5D677-A988-4B85-AC82-F78325E4C9C8}

TyPe MATERIAL. - Holotype. Colombia • ơ; Quebrada El Jordán, El Contento Village, San José de Oriente, La Paz, Cesar; $10^{\circ} 17^{\prime} 40.4{ }^{\prime \prime} \mathrm{N}$, 7255'52.1”W; 13.VIII.2015; C. M. López-Orozco leg.; CUDCCRU 104.

Paratypes. Colombia. $10^{\top 7}$ (parts in micropreparations); same locality and date as for holotype; Y. Herrera-Medina leg.; CUDC-CRU $105 \cdot 1 \%$ (parts in micropreparations); same locality and date as holotype; Y. Herrera-Medina leg.; CUDC-CRU $106 \bullet 1$ o , 4 \%; same locality and date as for holotype; C. M. López-Orozco leg.; ICN-CI-87 4 O $0^{7}, 6$ \% s same locality and date as for holotype; C. M. López-Orozco leg.; CUDC-CRU-34・4 o; Cerro Pintao, La Jagua del Pilar, La Guajira; $10^{\circ} 25^{\prime} 41.8^{\prime \prime} \mathrm{N}, 72^{\circ} 56^{\prime} 8.3^{\prime \prime} \mathrm{W}$; 10.VIII.2015; C. M. López-Orozco leg.; CUDC-CRU-50.
ETymology. - The new species name honours the University of Cartagena (UDC), on the 193rd anniversary of its foundation, which has contributed to the academic and research training of professionals in different science fields.

\section{DESCRIPTION}

Maximum body size: male $6.9 \mathrm{~mm} \times 3 \mathrm{~mm}$ (holotype); female $7 \mathrm{~mm} \times 2.5 \mathrm{~mm}$. Body as in Fig. 7A. Colour dark brown: antennae and uropods weakly pigmented; cephalon with irregular unpigmented spots; pereon with longitudinal unpigmented spots on paramedian region, median portion strongly pigmented, epimera pigmented; pleon and telson strongly pigmented, telson one unpigmented spot on median region (Fig. 7A). Dorsal surface bearing short triangular scale-setae (Fig. 7B). Cephalon (Fig. 7C, D) lateral lobes and frontal line absent, supraantennal line straight; vertex dorsoventrally flattened with prominent compound eyes on lateral protrusions; eyes with 27 ommatidia arranged in four 


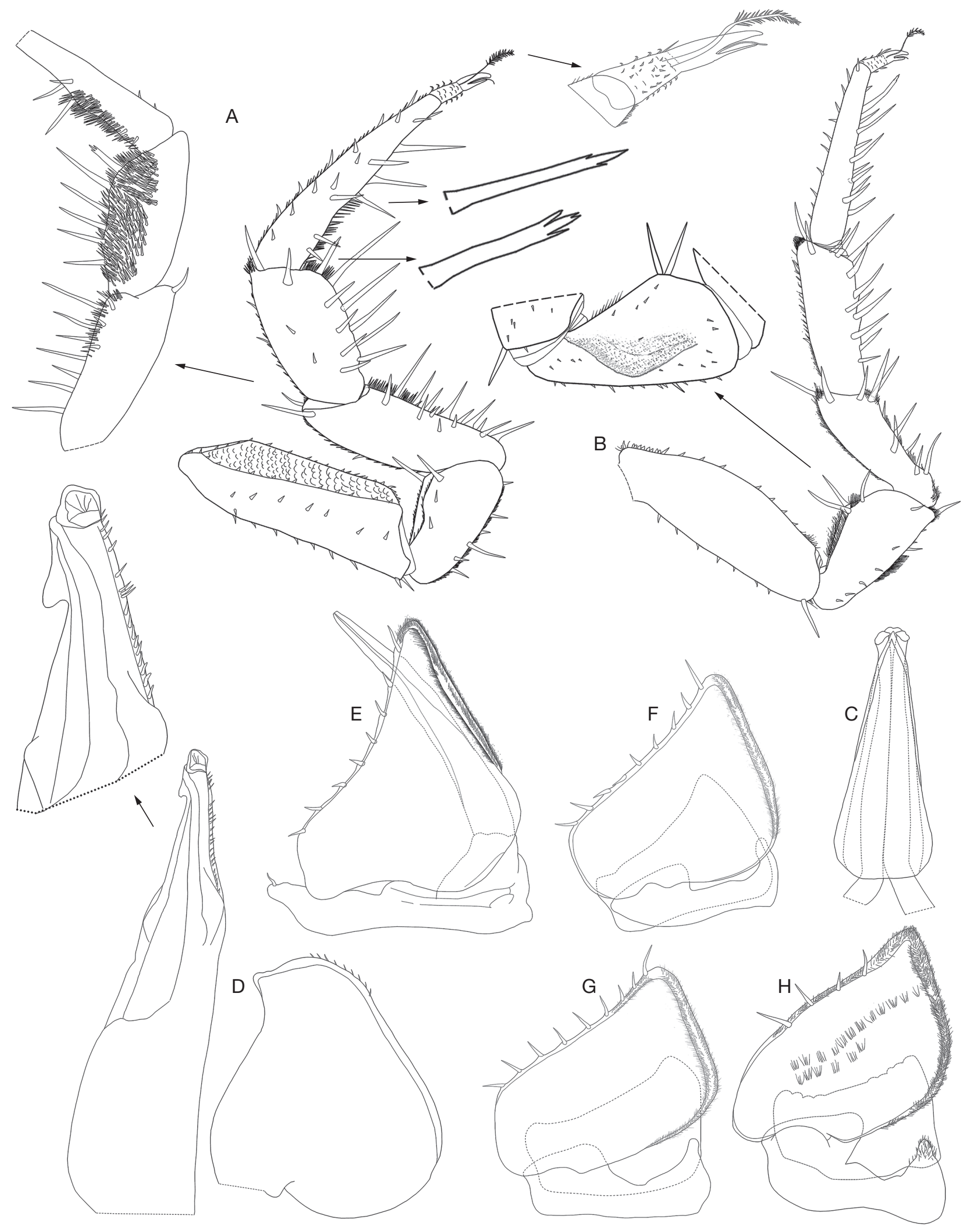

FIG. 6. - Ischioscia perijaensis Carpio-Díaz, López-Orozco \& Campos-Filho n. sp., male paratype (CUDC-CRU 40): A, pereopod 1; B, pereopod 7; C, genital papilla; D, pleopod 1, exopod (right), endopod (left); E, pleopod 2; F, pleopod 3; G, pleopod 4; H, pleopod 5. 

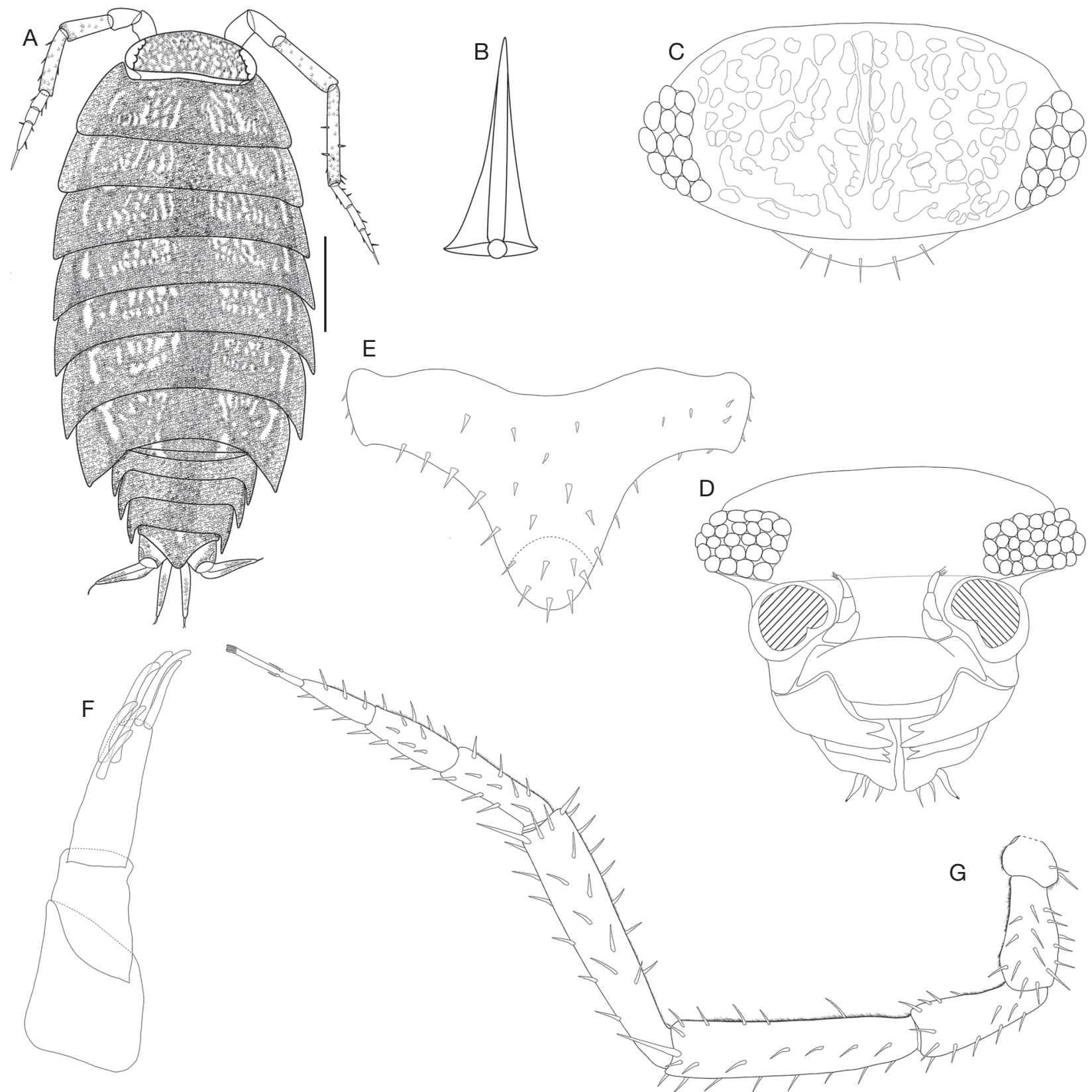

FlG. 7. - Ischioscia unicartagenae Campos-Filho, Carpio-Díaz \& López-Orozco n. sp., female paratype (CUDC-CRU 106). A, habitus, dorsal view; B, dorsal scale-seta; C, cephalon, dorsal view; D, cephalon, frontal view; E, telson; F, antennula; G, antenna. Scale bar: $1 \mathrm{~mm}$.

rows. Pleon (Fig. 7A) narrower than pereon, neopleurae 3-5 well developed, directed backwards. Telson (Fig. 7E) with lateral margins concave, apex rounded. Antennula (Fig. 7F) of three articles, distal article bearing five lateral aesthetascs plus apical pair. Antenna (Fig. 7G) when extended posteriorly reaching posterior margin of pereonite 4; flagellum of three articles subequal in length, apical organ very long. Mandibles with molar penicil composed of 6 to 7 branches, left mandible (Fig. $8 \mathrm{~A}$ ) with $2+1$ penicils, right mandible (Fig. 8B) with $1+1$ penicils. Maxillula (Fig. 8C) inner endite with distal margin rounded, outer distal margin with tip and bearing two hairy penicils; outer endite with $5+5$ teeth, three of them with cleft apex. Maxilla (Fig. 8D) outer lobe more than twice as wide as inner lobe, distal margin rounded covered with setae; inner lobe rounded bearing thick setae. Maxilliped (Fig. 8E) basis rectangular bearing sparse setae; palp with one seta on proximal article, outer distal margin with fringe of thin setae; endite sub-rectangular, ventral and dorsal surfaces hairy, medial seta surpassing distal margin, outer distal portion with one seta. Uropod (Fig. 8F) protopod and exopod grooved on lateral margin, exopod longer than endopod, endopod almost at same level of exopod. Pereopods 1-7 long and slender, sternal margin bearing sparse long setae; carpus 1 with transverse anten- 


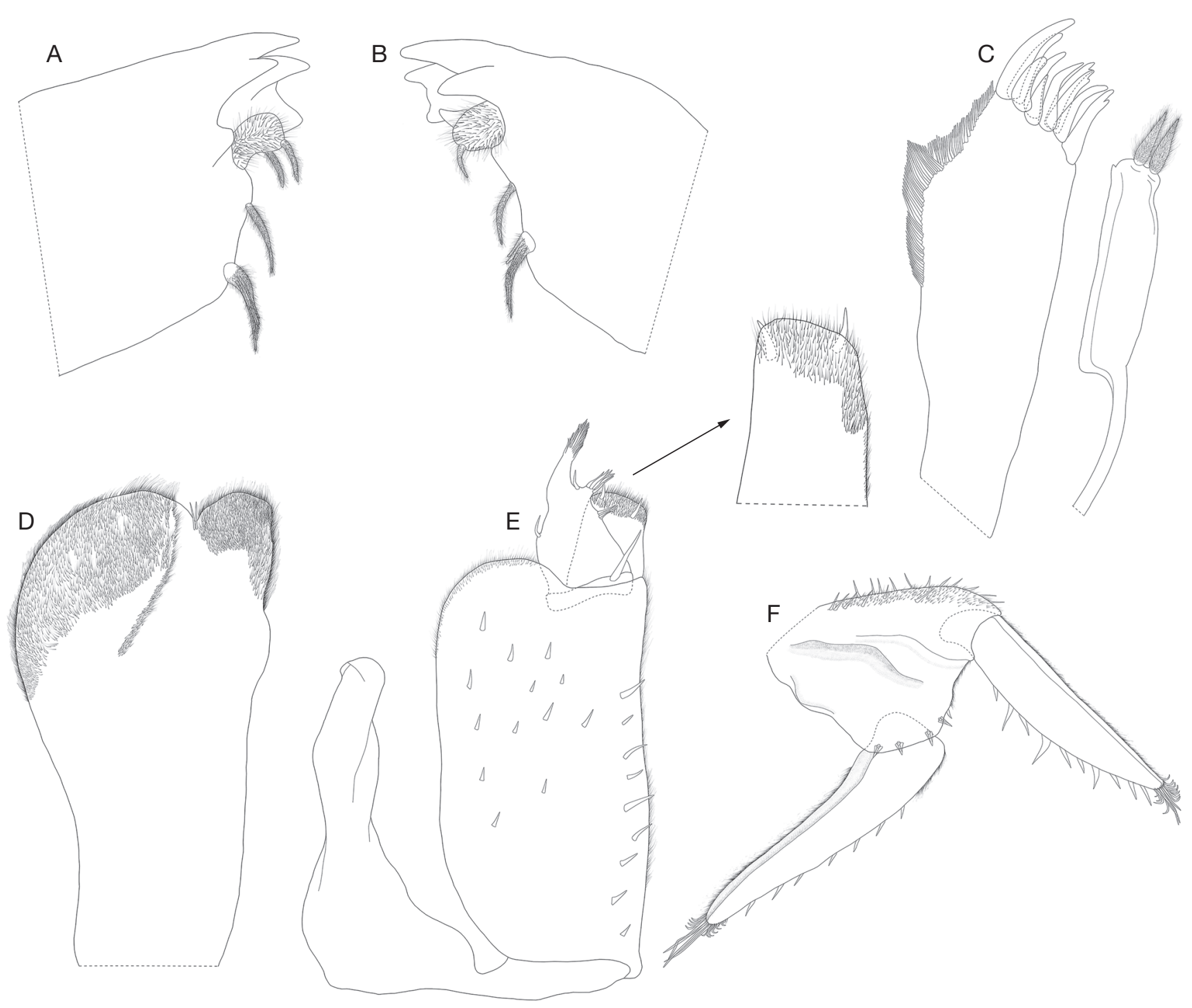

FIG. 8. - Ischioscia unicartagenae Campos-Filho, Carpio-Díaz \& López-Orozco n. sp., female paratype (CUDC-CRU 106). A, left mandible; B, right mandible; C, maxillula inner endite (right), outer endite (left); D, maxilla; E, maxilliped; F, uropod.

nal grooming brush; dactylus of two claws, inner claw not surpassing outer claw, ungual seta longer than outer claw, dactylar seta apically plumose. Pleopod exopods without respiratory areas.

\section{Male}

Pereopod 1 (Fig. 9A) merus and carpus with dense field of setae. Pereopod 7 (Fig. 9B) without any morphological modifications. Genital papilla (Fig. 9C) truncated apically, triangular ventral shield and two apical orifices. Pleopod 1 (Fig. 9D) exopod cordiform, distal margin rounded, outer margin with lateral incision, lateral process short and rounded; endopod stout, distal portion straight, apex rounded and arched bearing row of small setae on medial margin, outer distal margin bearing subapical small lobe. Pleopod 2 (Fig. 9E) exopod triangular, outer margin concave bearing several setae; endopod stout, slightly longer than exopod. Pleopods 3 and 4 as in Fig. 9F and $\mathrm{G}$, respectively. Pleopod 5 (Fig. 9H) exopod triangular, outer margin almost straight bearing three setae, median portion with transverse rows of thin setae.

REMARKS

In the shape of the male pleopod 1 endopod Ischioscia unicartagenae Campos-Filho, Carpio-Díaz \& López-Orozco n. sp. is similar to I. martinae Leistikow, 1997 and I. elongata Leistikow, 1997, but it is readily distinguishable in the shape of the male pleopod 1 exopod. In the shape of the male pleopod 1 exopod I. unicartagenae Campos-Filho, Carpio-Díaz \& López-Orozco n. sp. resembles I. curvaculeus Leistikow, 2001, but it differs in the cephalon without lamina frontalis, broader distal portion of telson, male pereopod 7 merus without proximal lobe, and male pleopod 1 endopod stout. Moreover, I. unicartagenae Campos-Filho, Carpio-Díaz \& López-Orozco n. sp. differs from I. herrerai López-Orozco, Carpio-Díaz \& Campos-Filho n. sp. and I. perijaensis Carpio-Díaz, López-Orozco \& Campos-Filho n. sp. in the shape of the male pleopod 1 exopod. 


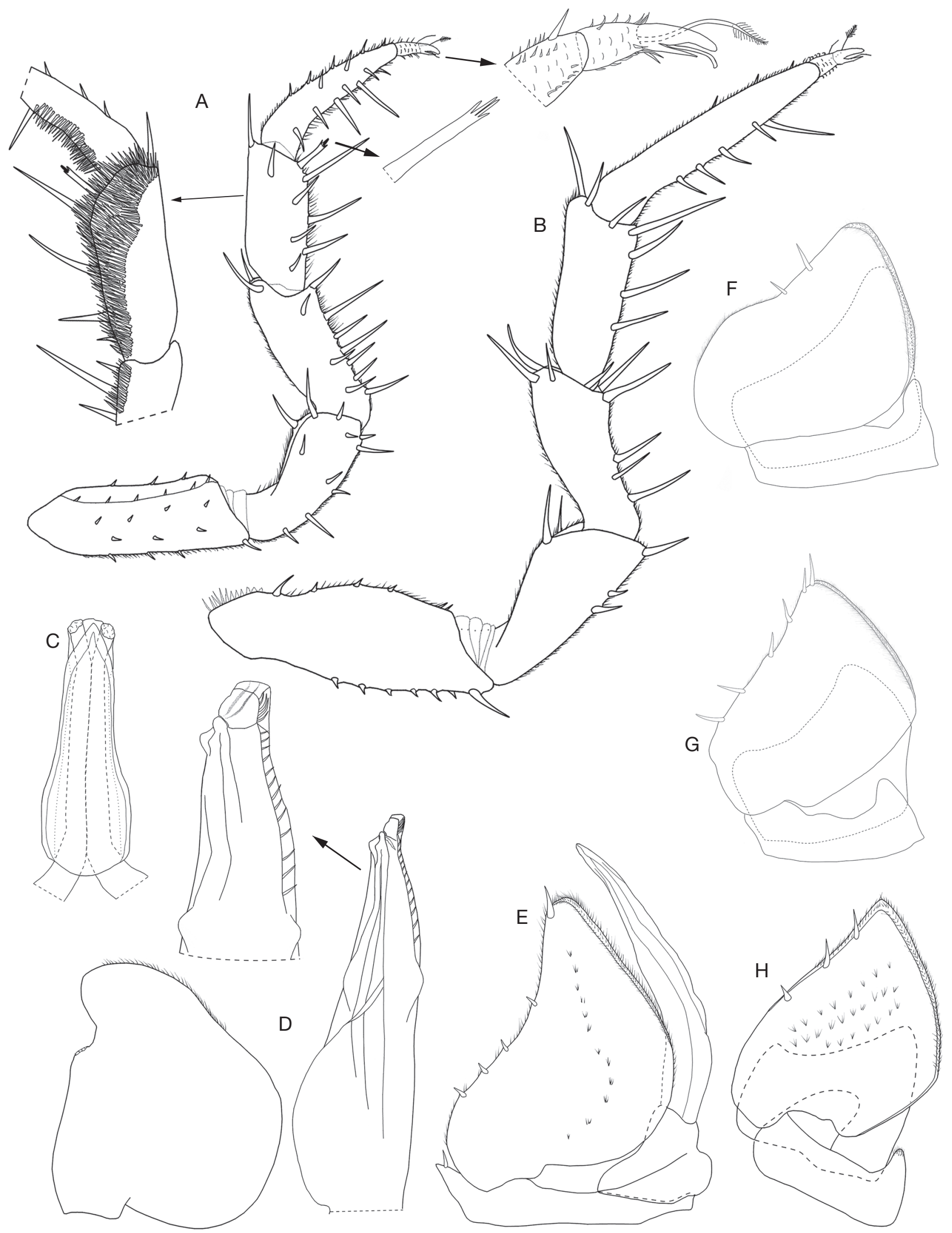

FIG. 9. - Ischioscia unicartagenae Campos-Filho, Carpio-Díaz \& López-Orozco n. sp., male paratype (CUDC-CRU 105). A, pereopod 1; B, pereopod 7; C, genital papilla; D, pleopod 1, exopod (left), endopod (right); E, pleopod 2; F, pleopod 3; G, pleopod 4; H, pleopod 5. 


\section{KeY TO THE SPECIES OF ISCHIOSCIA VERHOEF, 1928}

1. Pereonites 1-7 dorsally pigmented in brown colour with typical unpigmented spots at muscle insertions; male pleopod 1 exopod cordiform

- Pereonites 1 and 5 completely pigmented, 2-4 and 7 with well pigmented areas or spots, conferring zebra-like appearance; male pleopod 1 exopod sub-rectangular, lateral process not developed, outer distal margin serrate near indentation I. zebricolor Leistikow, 1999 (Leistikow 1999: pls 1-5).

2. Male pereopods 1-3 carpus strongly enlarged, sometimes pereopod 4 carpus ...................................... 13

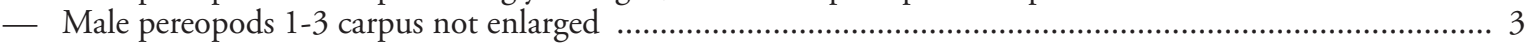

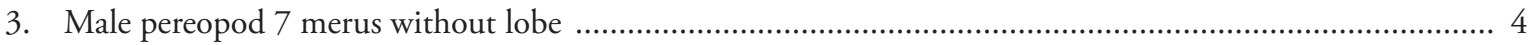

- Male pereopod 7 merus with proximal lobe ........... I. curvaculeus Leistikow, 2001 (Leistikow 2001c: pls 1-5).

4. Male pleopod 1 exopod with lateral process directed outwards (surpassing outer margin) ......................... 5

— Male pleopod 1 exopod without lateral process directed downwards (or not surpassing outer margin) $\quad \ldots . . . .10$

5. Dactylar seta surpassing outer claw and apically plumose

- Dactylar seta not surpassing outer claw and apically pointed

I. fasciifrons Leistikow, 2001 (Leistikow 2001b: figs 1-4).

6. Male pereopod 7 ischium with rounded depression on rostral surface 7

— Male pereopod 7 ischium without rounded depression on rostral surface ............................................. 8

7. Male pereopod 7 ischium with short rounded depression on rostral surface; male pleopod 1 exopod with lateral process well developed and obliquely directed outwards, endopod with reduced subapical outer lobe I. plurimaculata Leistikow, 2000 (Leistikow 2000: figs 12-16).

- Male pereopod 7 ischium with wide rounded depression on rostral surface; male pleopod 1 exopod with lateral process reduced and laterally directed outwards, endopod with developed subapical outer lobe

I. perijaensis Carpio-Díaz, López-Orozco \& Campos-Filho n. sp.

8. Male pereopod 2 carpus with dense field of setae of about half of its width; male pleopod 1 exopod with lateral process directed outward, downwards or reduced

- Male pereopod 2 carpus with dense field of setae of about one quarter of its width; male pleopod 1 exopod with lateral process obliquely directed outwards and distal margin rounded I. bolivari Vandel, 1968 (Leistikow \& Schmidt 2002: figs 22-27).

9. Male pleopod 1 exopod with lateral process directed outwards and distal margin straight

I. muelleri Leistikow, 1997 (Leistikow 1997: figs 14-19).

- Male pleopod 1 exopod with lateral process obliquely directed outwards and distal margin rounded I. cadoangelis Leistikow, 2000 (Leistikow 2001b: figs 1-6).

10. Male pleopod 2 endopod slightly longer than exopod

11

- Male pleopod 2 endopod twice as long as exopod I. andina (Vandel, 1968) (Vandel 1968: fig. 11).

11. Male pereopod 7 ischium with fringe of setae on sternal margin 12

- Male pereopod 7 ischium without fringe of setae on sternal margin I. stenocarpa Schmalfuss, 1980 (Schmalfuss 1980: figs 9-14).

12. Cephalon with frontal line marked; maxilla subequal lobes; pereopods 1 and 2 merus and carpus with dense field of setae; dactylar seta apically enlarged, conferring spatuliform-like appearance; male pleopod 1 endopod without subapical lobe ......... I. amazonica Lemos de Castro, 1965 (Leistikow \& Schmidt 2002: figs 17-21).

- Cephalon without frontal line well-marked; maxilla outer lobe wider than inner lobe; pereopod 2 merus and carpus without dense field of setae; dactylar seta apically plumose; male pleopod 1 exopod with lateral process rounded, endopod with short subapical lobe ............ I. unicartagenae Campos-Filho, Carpio-Díaz \& López-Orozco n. sp.

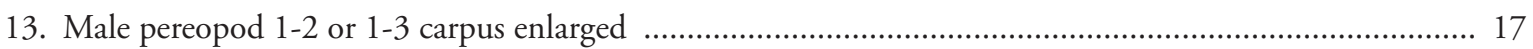

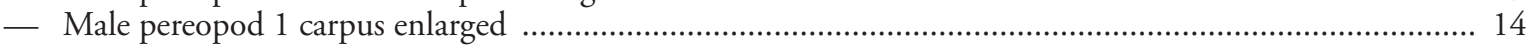

14. Male pereopod 7 ischium with distal sternal portion prominent ..................................................... 15

— Male pereopod 7 ischium with distal sternal portion not prominent ................................................... 16

15. Dactylar seta apically enlarged, conferring spatuliform-like appearance; male pereopod 7 ischium with sternal margin concave and rounded depression on rostral surface ... I. parie Leistikow, 2001 (Leistikow 2001b: figs 13-16).

- Dactylar seta apically plumose; male pereopod 7 ischium with sternal margin straight and lobe bearing one strong setae on caudal surface

I. herrerai López-Orozco, Carpio-Díaz \& Campos-Filho n. sp. 
16. Male pereopod 7 ischium with sternal margin concave bearing dense fringe of thin setae; male pleopod 1 exopod with lateral process directed downwards, endopod with distal portion sinuous I. irmleri Schmalfuss, 1980 (Schmalfuss 1980: figs 27-31).

- Male pereopod 7 ischium with sternal margin sinuous and without fringe of thin setae; pleopod 1 exopod with lateral process not developed, endopod with distal portion straight

I. sturmi (Vandel, 1972) (Leistikow \& Schmidt 2002: figs 11-16).

17. Male pereopod 1-2 carpus enlarged (sometimes male pereopod 3 carpus slightly enlarged) 18

- Male pereopod 1-3 carpus enlarged

18. Male pleopod 1 exopod with lateral process directed outwards (surpassing outer margin), endopod with subapical lobe

- Male pleopod 1 exopod with lateral process directed downwards, endopod without subapical lobe ................ I. longicauda Schmalfuss, 1980 (Schmalfuss 1980: figs 21-26).

19. Male pereopod 7 ischium with distal sternal portion prominent 20

— Male pereopod 7 ischium without distal sternal portion prominent ..................................................... 22

20. Dactylar seta longer than outer claw and apically plumose 21

- Dactylar seta shorter than outer claw and apically acute I. marmorata Leistikow, 2000 (Leistikow 2000: figs 7-11).

21. Maxilla outer lobe wider than inner lobe; male pereopod 3 carpus with wide field of setae reaching half of its width; male pereopod 7 ischium with distal sternal portion distinctly prominent

I. guamae Leistikow, 2001 (Leistikow 2001b: figs 17-20).

- Maxilla with lobes subequal width; male pereopod 3 carpus with wide field of setae in almost all its width; male pereopod 7 ischium with distal sternal portion slightly prominent

I. mineri (Van Name, 1936) (Leistikow 2001d: figs 1-4).

22. Cephalon with frontal line not well marked; maxilla with lobes subequal in width; male pereopod 3 carpus with wide field of setae of about one quarter of its width; male pleopod 1 exopod with distal margin straight ........

I. elongata Leistikow, 1997 (Leistikow 1997: figs 20-25).

- Cephalon with frontal line well marked; maxilla outer lobe wider than inner lobe; male pereopod 3 carpus slightly enlarged, wide field of setae of about half of its width; male pleopod 1 exopod with distal margin rounded ... I. martinae Leistikow, 1997 (Leistikow 1997: figs 8-13)

23. Male pereopod 4 carpus enlarged, dense field of setae covering almost all carpus width; male pereopod 7 ischium with distal sternal portion slightly prominent ..... I. quadrispinis Leistikow, 2000 (Leistikow 2000: figs 17-22).

- Male pereopod 4 carpus not enlarged; male pereopod 7 ischium with distal sternal portion prominent or not prominent

24. Male pleopod 1 exopod with lateral process directed downwards

— Male pleopod 1 exopod with lateral process directed outwards ......................................................... 27

25. Male pereopods 1-3 carpus enlargement and wide field of setae progressively decreasing; male pereopod 7 ischium with distal margin strongly prominent or not prominent ….................................................. 26

- Male pereopods 1-3 carpus strongly enlarged; male pereopod 7 ischium with distal margin strongly prominent bearing distinct brush of thin seate ........................ I. panamensis Leistikow, 1999 (Leistikow 1999: figs 6-9).

26. Cephalon with frontal line well marked; male pereopod 7 ischium with sternal margin concave and distal sternal portion not prominent ................................. I. hanagarthi Schmalfuss, 1980 (Schmalfuss 1980: figs 15-20).

- Cephalon with frontal line not well marked; male pereopod 7 ischium with sternal margin straight and concave depression on rostral surface ................................. I. colorata Leistikow, 2001 (Leistikow 2001b: figs 9-12).

27. Male pereopod 7 ischium with distal sternal prominence triangular; male pleopod 1 endopod with apical portion directed downwards

- Male pereopod 7 ischium with distal sternal prominence rounded; male pleopod 1 endopod with apical portion slightly bent outwards I. trifasciata Leistikow, 2001 (Leistikow 2001b: figs 21-24).

28. Male pereopod 6 merus with proximal portion swelled, conferring a lobe aspect; male pereopod 7 ischium without depressions on rostral surface; male pleopod 1 endopod with triangular subapical lobe directed downwards ..................................................................... I. variegata (Dollfus, 1893) (Leistikow 1997: figs 27-32).

- Male pereopod 6 merus not swelled on proximal portion; male pereopod 7 ischium with two rounded depressions on rostral surface; male pleopod 1 endopod with triangular subapical lobe directed upwards ..... I. hirsuta Leistikow, 2001 (Leistikow 2001b: figs 5-8). 


\section{DISCUSSION}

The access to the biodiversity constitutes one of the first steps to develop further studies in other science fields (Dudgeon et al. 2006; Lamoreux et al. 2006; Tundisi \& Matsumura-Tundisi 2008; Rull 2011). Since many ecosystems in the world are suffering high alterations, such as habitat loss due to urban expansions, fragmentation and climate change, knowledge of biodiversity will identify priority areas for conservation and management strategies (Myers et al. 2000).

Considering the distribution of the species of Ischioscia (see Schmalfuss 2003), together with the high diversity of ecosystems in the Neotropical region (Olson et al. 2001), the number of species in the genus is certainly not complete. Most species of Ischioscia occur at high altitudes (up to $4200 \mathrm{~m}$ a.s.l.), which probably is related to historic events (e.g. Andean uplift, tectonic events, marine transgressions) (Haffer 2008; Weir \& Price 2011; Morrone 2014; Dagosta \& de Pinna 2017). Future studies are needed for a better understanding about the biodiversity and ecological-evolutionary processes of the species of the genus.

The three new species of Ischioscia were collected in Quebrada El Jordán, San José de Oriente (c. $2800 \mathrm{~m}$ a.s.1.), and I. herrerai López-Orozco, Carpio-Díaz \& Campos-Filho n. sp. and I. unicartagenae Campos-Filho, Carpio-Díaz \& LópezOrozco n. sp. also in Cerro Pintao, La Jagua del Pilar ( $c$. $2800 \mathrm{~m}$ a.s.l.). The specimens were found during the morning under rocks, trunks and among the litter together with other representatives of the families Philosciidae and Styloniscidae Vandel, 1952. In other works on Neotropical Philosciidae the presence of more than one species living together at the same micro-environment was recorded, e.g., Ischioscia (Leistikow \& Schmidt 2002), and Atlantoscia Ferrara \& Taiti, 1981 (Zimmermann et al. 2015). At Cerro Pintao, the specimens of I. herrarai López-Orozco, Carpio-Díaz \& Campos-Filho n. sp. and I. unicartagenae Campos-Filho, Carpio-Díaz \& López-Orozco n. sp. were collected during the afternoon on leaf-litter and under rocks, also coexisting with other species of Philosciidae and Scleropactidae Verhoeff, 1938.

\section{Acknowledgements}

We are grateful to "Estudios técnicos, sociales, económicos y ambientales, con su respectiva cartografía temática, correspondiente al entorno local, del complejo de páramo Perijá en jurisdicción de la Corporación Autónoma Regional del Cesar (CORPOCESAR) y la Corporación Autónoma Regional de La Guajira (CORPOGUAJIRA)", financed by the Instituto de Investigaciones Biológicas Alexander von Humboldt $(\mathrm{IAvH})$ and Fundación Prosierra; to the colleagues Yeison Herrera-Medina, Andrés Camilo Montes-Correa, César Valberde, Leonardo Dalí Granados, Nelson Jiménez, Anderson Guerrero, Adolfo del Portillo, Miguel Arévalo, Efraín Rada, Pedro Torrijos, Francisco Troncoso and Miguel Cantillo for their assistance during expeditions in Serranía de Perijá; to Vicerrectoría de Investigaciones and to Grupo de Investigación Hidrobiología of the University of Cartagena for the scholarship to CML-O (Resolución Nº1277-2016, Programa de Movilidad Internacional de Estudiantes - International Program of Student Mobility) and for the financial support to the Grupo de Investigación Hidrobiología (Plan de Fortalecimiento Acta 065-2018). This study was financed in part by CAPES with the Coordenação de Aperfeiçoamento de Pessoal de Nível Superior, Finance Code 001, and a PNPD scholarship to ISC-F (CAPES/PNPD/UFCG/CTRN/PPGRN/201713705-5). The reviewers are particularly acknowledged for their precious suggestions that greatly improved the text.

\section{REFERENCES}

Arellano-P. H., Rangel-Ch. J. O. \& García-M. A. M. 2007. Clima y Topoclima, in RANGEL J. O. (ed.), Colombia Diversidad Biótica V: La alta montaña de la Serranía de Perijá. Instituto de Ciencias Naturales, Bogotá: 19-41.

Campos-Filho I. S., Araujo P. B., Bichuette M. E., Trajano E. \& TAITI S. 2014. - Terrestrial isopods (Crustacea: Isopoda: Oniscidea) from Brazilian caves. Zoological Journal of the Linnean Society 172 (2): 360-425. https://doi.org/10.1111/zoj.12172

Campos-Filho I. S., Montesanto G., Araujo P. B. \& Taiti S. 2017. - New species and new records of terrestrial isopods (Crustacea, Isopoda, Oniscidea) from Brazil. Iheringia, Série Zoologia 107: e2017034. https://doi.org/10.1590/1678-4766e2017034

Campos-Filho I. S., Cardoso G. M. \& Aguiar J. O. 2018. Catalogue of terrestrial isopods (Crustacea, Isopoda, Oniscidea) from Brazil: an update with some considerations. Nauplius 26: e2018038. https://doi.org/10.1590/2358-2936e2018038

Coleman C. O. 2006. - Substituting time-consuming pencil drawings in arthropod taxonomy using stacks of digital photographs. Zootaxa 1360: 61-68. https://doi.org/10.11646/zootaxa.1360.1.4

Dagosta F. C. P. \& DE PInNa M. 2017. — Biogeography of Amazonian fishes: deconstructing river basins as biogeographic units. Neotropical Ichthyology 15 (3): e170034. https://doi. org/10.1590/1982-0224-20170034

Dudgeon D., Arthington A. H., Gessner M. O., Kawabata Z.-I., Knowler D. J., Lévêque C., Naiman R. J., PrieurRichard A. -H., Soto D., Stiassny M. L. J. \& Sullivan C. A. 2006. - Freshwater Biodiversity: importance, threats, status and conservation challenges. Biological Reviews 81 (2): 163-182. https://doi.org/10.1017/S1464793105006950

HAFFER J. 2008. - Hypotheses to explain the origin of species in Amazonia. Brazilian Journal of Biology 68 (4, Suppl.): 917-947. https://doi.org/10.1590/S1519-69842008000500003

Lamoreux J. F., Morrison J. C., Ricketts T. H., Olson D. M., MCKNight M. W. \& SHUGART H. H. 2006. - Global tests of biodiversity concordance and the importance of endemism. Nature 440 (7081): 212-214. https://doi.org/10.1038/nature04291

LEISTIKOW A. 1997. - Terrestrial isopods from Costa Rica and a redescription of Ischioscia variegata (Dollfus, 1893) (Crustacea: Isopoda: Oniscidea). Canadian Journal of Zoology 75 (9): 14151464. https://doi.org/10.1139/z97-768

LeISTIKOW A. 1999. - New species of the genera Ischioscia and Andenoniscus, terrestrial isopods from Panama (Crustacea, Isopoda). Studies on Neotropical Fauna and Environment 34 (3): 156-175. https://doi.org/10.1076/snfe.34.3.156.8911

LEISTIKOW A. 2000. - The terrestrial isopod genus Ischioscia in Costa Rica: new species and records, and an analysis of its phylogeny (Crustacea, Isopoda, Oniscidea). Mitteilungen aus dem Museum für Naturkunde in Berlin 76 (1): 19-49. https://doi.org/10.1002/ mmnz.20000760104

LeISTIKOW A. 2001a. - Phylogeny and Biogeography of South American Crinocheta, traditionally placed in the family "Philosciidae" (Crustacea: Isopoda: Oniscidea). Organism Diversity and 
Evolution, 1(Electr. Suppl. 4): 1-85. http://www.senckenberg. uni-frankfurt.de/odes/01-04.htm

LeIsTIKOW A. 2001b. — The genus Ischioscia Verhoeff, 1928 in Venezuela, with description of six new species (Crustacea, Oniscidea, Philosciidae). Bulletin of the Natural History Museum 67 (2): 137-168.

LeISTIKOW A. 2001c. - A new Species of Terrestrial Isopoda from the Sierra Nevada de Santa Marta, Colombia (Crustacea: Oniscidea: Crinocheta). Studies on Neotropical Fauna and Environment 36 (2): 151-158. https://doi.org/10.1076/snfe.36.2.151.2140

LEISTIKOW A. 2001d. - New genera of terrestrial isopods (Oniscidea: Philosciidae) from South America, with remarks on some species, in Kensley B. \& BRUsCA R. (eds), Isopod Systematics and Evolution. Leiden, Brill. Crustacean Issues, 13: 19-49.

LEISTIKOW A. \& SCHMIDT C. 2002. - The phylogeny of the genus Ischioscia Verhoeff, 1928, with redescriptions of three species (Crustacea: Isopoda: Oniscidea). Organism Diversity and Evolution 2 (2): 139-178. https://doi.org/10.1078/1439-6092-00039

López-Orozco C. M., Carpio-Díaz Y. M., Navas S. G. R. \& CAmpos-FilHo I. S. 2016. - A new species and first record of Androdeloscia (Oniscidea: Philosciidae) from Colombia. Studies on Neotropical Fauna and Environment 52 (1): 1-7. https://doi. org/10.1080/01650521.2016.1254861

López-Orozco C. M., Carpio-Díaz Y. M., Navas S. G. R. \& Campos-Filho I. S. 2017. - A new species and first record of Pulmoniscus Leistikow, 2001 (Isopoda, Oniscidea, Philosciidae) from Colombia. Nauplius 25: e2017014. https://doi. org/10.1590/2358-2936e2017014

MonTESANTO G. 2015. - A fast GNU method to draw accurate scientific illustrations for taxonomy. ZooKeys 515: 191-206. https://doi.org/10.3897/zookeys.515.9459

Montesanto G. 2016. — Drawing setae: a GNU way for digital scientific illustrations. Nauplius 24: e2016017. https://doi. org/10.1590/2358-2936e2016017

MORRONE J. J. 2014. - Cladistic biogeography of the Neotropical region: identifying the main events in the diversification of the terrestrial biota. Cladistics 30: 202-214. https://doi.org/10.11646/ zootaxa.3782.1.1

Myers N., Mittermeier R. A., Mittermeier C. G., Fonseca G. A. B. \& KENT J. 2000. - Biodiversity hotspots for conservation priorities. Nature 403: 853-858. https://doi.org/10.1038/35002501

Olson D. M., Dinerstein E., Wikramanayake E. D., Burgess N. D., Powell G. V. N., Underwood E. C., D'Amico J. A., ItouA I., Strand H. E., Morrison J. C., Loucks C. J., Allnutt T. F., Ricketts T. H., Kura Y., LamoreuX J. F., Wettengel W.
W., HedaO P. \& KASSEM K. R. 2001. — Terrestrial ecoregions of the world: a new map of life on Earth. BioScience 51 (11): 933938. https://doi.org/10.1641/0006-3568(2001)051[0933:TEO TWA]2.0.CO;2

Rubel F. \& KotTeK M. 2010. — Observed and projected climate shifts 1901-2100 depicted by world maps of the Köppen-Geiger climate classification. Meteorologische Zeitschrift 19: 135-141. https://doi.org/10.1127/0941-2948/2010/0430

RulL V. 2011. - Neotropical biodiversity: timing and potential drivers. Trends in Ecology and Evolution 26 (10): 508-513. https:// doi.org/10.1016/j.tree.2011.05.011

SCHMALFUSS H. 1980. - A revision of the neotropical genus Ischioscia Verhoeff, with descriptions of four new species (Isopoda, Philosciidae). Studies on Neotropical Fauna and Environment 15: 125-139. https://doi.org/10.1080/01650528009360570

SCHMALFuss H. 2003. - World catalog of terrestrial isopods (Isopoda: Oniscidea). Stuttgarter Beiträge zur Naturkunde, Serie A 654: 1-341.

Sfenthourakis S. \& TaITI S. 2015. - Patterns of taxonomic diversity among terrestrial isopods. ZooKeys 515: 13-25. https:// doi.org/10.3897/zookeys.515.9332

TAiti S. 2016. - Oniscidea, in World list of Marine, Freshwater and Terrestrial Crustacea Isopoda. National Museum of Natural History Smithsonian Institution, Washington D.C., USA. Available at: http://www.marinespecies.org/aphia. php? $p=$ taxdetails\&id=146505. Accessed 10 Jun 2018.

Tundisi J. G. \& Matsumura-Tundisi T. 2008. — Biodiversity in the Neotropics: ecological, economic and social values. Brazilian Journal of Biology 68 (4, Suppl.): 913-915. https://doi. org/10.1590/S1519-69842008000500002

VANDEL A. 1968. — Isopodes terrestres, in LELEUP N. J. (ed.), Mission zoologique belge aux iles Galapagos et en Ecuador. Institut royal des Sciences Naturelles de Belgique, Brussels, 37-168.

VANDEL A. 1972. — Les isopodes terrestres de la Colombie. Studies on Neotropical Fauna and Environment 7: 147-172. https://doi. org/10.1080/01650527209360441

WEIR J. T. \& PRICE M. 2011. — Andean uplift promotes lowland speciation through vicariance and dispersal in Dendrocincla woodcreepers. Molecular Ecology 20 (21): 4550-4563. https:// doi.org/10.1111/j.1365-294X.2011.05294.x

ZimmermanN B. L., CAMPOS-Filho I. S., Deprá M. \& Araujo P. B. 2015. - Taxonomy and molecular phylogeny of the Neotropical genus Atlantoscia (Oniscidea, Philosciidae): DNA barcoding and description of two new species. Zoological Journal of the Linnean Society 174 (4): 702-717. https://doi.org/10.1111/zoj.12256 